\title{
A critical review of biomarkers used for monitoring human exposure to lead: advantages, limitations and future needs
}

\author{
Uma avaliação crítica sobre biomarcadores \\ utilizados para o monitoramento biológico \\ de exposição ao chumbo: vantagens, \\ limitações e perspectivas futuras
}

Fernando Barbosa Jr 1

José Eduardo Tanus-Santos 2

Raquel Fernanda Gerlach 3

Patrick J. Parsons 4

\footnotetext{
${ }^{1}$ Departamento de Análises Clínicas, Toxicológicas e Bromatológicas, Faculdade de Ciências Farmacêuticas de Ribeirão Preto-USP. Avenida do Café s/n, Monte Alegre, 14049-903, Ribeirão Preto SP. fbarbosa@fcfrp.usp.br 2 Departamento de Farmacologia, Faculdade de Medicina de Ribeirão Preto-USP.

3 Departamento de

Morfologia, Estomatologia

e Fisiologia, Faculdade

de Odontologia de Ribeirão Preto-USP.

4 Wadsworth Center,

New York State

Abstract Lead concentration in whole blood (Blood-Pb) is the primary biomarker used to monitor exposure to this metallic element. However, the difficulty in assessing the exact nature of $\mathrm{Pb}$ exposure is dependent not so much on problems with current analytical methodologies, but rather on the complex toxicokinetics of $\mathrm{Pb}$ within various body compartments. If we are to differentiate more effectively between $\mathrm{Pb}$ that is stored in the body for years and $\mathrm{Pb}$ from recent exposure, information on other biomarkers of exposure may be needed. None of the current biomarkers of internal $\mathrm{Pb}$ dose has yet been accepted by the scientific community as a reliable substitute for a Blood-Pb measurement. This review focuses on the limitations of biomarkers of $\mathrm{Pb}$ exposure, and the need to improve the accuracy of their measurement. We present here only the traditional analytical protocols in current use and we attempt to assess the influence of confounding variables on Blood-Pb levels. Finally, we discuss the interpretation of Blood-Pb data with respect to both external and endogenous $\mathrm{Pb}$ exposure, past or recent exposure, as well as the significance of lead determinations in human specimens including hair, nails, saliva, bone, blood, urine, feces, and exfoliated teeth.

Key words Lead, Biomonitoring, Biomarkers of exposure
Resumo A concentração de chumbo $(\mathrm{Pb})$ no sangue total $(\mathrm{Pb}-\mathrm{B})$ vem sendo comumente utilizada para monitorar a exposição a este elemento químico. Entretanto, a dificuldade em avaliar a natureza exata da exposição ao $\mathrm{Pb}$ é dependente não só de problemas inerentes a metodologias analíticas inapropriadas, bem como da toxicocinética complexa do Pb em compartimentos de nosso corpo. Se quisermos diferenciar mais efetivamente entre o Pb que está estocado no corpo por anos daquele proveniente de uma exposição recente, deverão ser obtidas informações pela análise de outros biomarcadores de exposição. Entretanto, nenhum dos biomarcadores de dose interna para Pbé aceito pela comunidade científica como substituto ao $\mathrm{Pb}$-B. O foco desta revisão está nas limitações de biomarcadores de exposição ao Pb e nas necessidades para melhorar a exatidão nas determinações. Procuramos apresentar somente os protocolos analíticos em uso corrente e tentamos avaliar a infuência de variáveis de confusão nos níveis de Pb-B. Finalmente, fizemos uma discussão sobre a interpretação dos dados de $\mathrm{Pb}$-B com respeito a fontes de exposição, sejam elas endógenas e exógenas, recente ou passada, bem como a importância das determinações de Pb no cabelo, unhas, saliva, ossos, sangue (plasma e sangue total), urina, fezes e dente decíduo.

Palavras-chave Chumbo, Biomonitoramento, Biomarcadores de exposição 


\section{Introduction}

Over the last two decades, atmospheric concentrations of lead $(\mathrm{Pb})$ have decreased significantly around the globe, as more and more nations have chosen to remove tetraethylead from gasoline (Thomas et al.1). However, humans may also be exposed to $\mathrm{Pb}$ through contaminated food, water, and house dust, and through remaining industrial activities, such as metal recycling and the battery industry. In the US, for example, although the use of lead in house paint peaked in 1940 and was banned in 1978, $40 \%$ of the nation's housing stock is estimated still to contain lead-based paint (Wakefield2).

After $\mathrm{Pb}$ enters the body, it can travel along several pathways, depending on its source and, by extension, its bioavailability. The fraction of $\mathrm{Pb}$ that is absorbed depends mainly on the physical and chemical form, particularly particle size and the solubility of the specific compound. Other important factors are specific to the exposed subject, such as age, gender, nutritional status and, possibly, genetic background (National Research Council ${ }^{3}$, ATSDR 4 ). One of the earliest toxicokinetics studies reported that $\mathrm{Pb}$, once absorbed into the blood compartment, has a mean biological half-life of about 40 days in adult males (Rabinowitz et al.5). The half-life in children and in pregnant women was reported to be longer, due to bone remodeling (Gulson et al.6, Manton et al.7). However, another study was unable to confirm this finding (Succop et al.8). Like many other "boneseeking" elements, $\mathrm{Pb}$ from blood is incorporated into calcified tissues such as bone and teeth, where it can remain for years (Rabinowitz ${ }^{9}$, O’Flaherty 10$)$. According to Rabinowitz', the "half-life" of $\mathrm{Pb}$ in bone (Bone$\mathrm{Pb}$ ) ranges from 10 to 30 years. However, the use of the term half-life to describe the biological clearance of $\mathrm{Pb}$ from bone implicitly makes assumptions about the kinetics of the process by which $\mathrm{Pb}$ is released. Some workers prefer to use the term "residence time", to avoid implying something more precise than what can be directly determined (D. Chettle, personal communication). From calcified tissue stores, $\mathrm{Pb}$ is slowly released, depending on bone turnover rates, which in turn are a function of the type of bone, whether compact (slow turnover) or trabecular (rapid turnover) (O'Flaherty 10 ). Brito et al. 11 reported that the release rate of $\mathrm{Pb}$ from bone varies with age and intensity of exposure. This group also examined es- timates of exchange rates amongst compartments (Brito12). The transfer of $\mathrm{Pb}$ from blood to other compartments was shown to be very much more rapid than the one-month estimate reported previously by others, with the overall clearance rate from blood (sum of rates from blood to cortical bone, to trabecular bone and to other tissue, implying a, "half-value of 10 to 12 days" (Brito ${ }^{12}$ ). This highlights the difference between the overall clearance viewed from outside, when no allowance can be made for recirculation, and actual transfer rates.

Physiological differences between children and adults account for much of the increased susceptibility of small children to the deleterious effects of $\mathrm{Pb}$ : whereas in adults $94 \%$ of $\mathrm{Pb}$ body burden is stored in bones and teeth, this proportion is only $70 \%$ in children (Barry 13 ). Besides, the continuous growth of young children implies constant bone remodeling for skeletal development (O'Flaherty10). This contributes to a state in which $\mathrm{Pb}$ stored in bone is continually released back into the blood compartment, as what has been described as "endogenous contamination" (Gulson et al.6). This process is particularly significant for pregnant women, since pregnancy also causes an increase in bone remodeling. The apparently limited success of various $\mathrm{Pb}$ hazard control measures in decreasing Blood-Pb levels in exposed children and pregnant women may reflect a constant bone resorption process (Rust et al.14). Interestingly, Popovic et al. 15 recently reported very different long-term $\mathrm{Pb}$ kinetics between men and women, with pre-menopausal women appearing to retain $\mathrm{Pb}$ more avidly or release $\mathrm{Pb}$ more slowly compared to postmenopausal women and men.

\section{Biomonitoring of human exposure to lead}

Biomonitoring for human exposure to $\mathrm{Pb}$ reflects an individual's current body burden, which is a function of recent and/or past exposure. Thus, the appropriate selection and measurement of biomarkers of lead exposure is of critical importance for health care management purposes, public health decision-making, and primary prevention activities in the future.

It is well known that $\mathrm{Pb}$ affects several enzymatic processes responsible for heme synthesis. $\mathrm{Pb}$ directly inhibits the activity of the cytoplasmic enzyme $\delta$-aminolevulinic acid dehy- 
dratase (ALA-D), resulting in a negative exponential relationship between ALA-D and Blood$\mathrm{Pb}$. There is also depression of coproporphyrinogen oxidase, resulting in increased coproporphyrin activity. $\mathrm{Pb}$ also interferes with the normal functioning of the intramitochondrial enzyme ferrochelatase that is directly responsible for the chelation of Fe by protoporphyrin. Failure to insert Fe into the protoporphyrin ring results in depressed heme formation and an accumulation of protoporphyrin; this in turn chelates $\mathrm{Zn}$ in place of $\mathrm{Fe}$, to form zinc protoporphyrin (ZPP). These effects also result in modifications of some other metabolite concentrations in urine (ALA-U), blood (ALA-B) and plasma (ALA-P), coproporphyrin in urine $(\mathrm{CP})$. The activities of pyrimidine nucleotidase $\left(\mathrm{P} 5{ }^{\prime} \mathrm{N}\right)$ and nicotinamide adenine dinucleotide synthase (NADS) are also modified in blood, after $\mathrm{Pb}$ exposure. Levels of these various metabolites in biological fluids have been used in the past to diagnose $\mathrm{Pb}$ poisoning, when direct $\mathrm{Pb}$ levels were difficult to obtain in tissues or body fluids (Leung16) or as information complementary to Blood-Pb test results. They are more accurately described as biomarkers for toxic effects of $\mathrm{Pb}$. In this review, we focus on markers that are more accurately defined as biomarkers of $\mathrm{Pb}$ exposure, i.e., $\mathrm{Pb}$ concentrations in biological tissues and fluids. Biomarkers for the toxic effects of $\mathrm{Pb}$ have been reviewed in some detail elsewhere (Sakai17).

Throughout the last five decades, whole blood has been the primary biological fluid used for assessment of $\mathrm{Pb}$ exposure, both for screening and diagnostic purposes, and for biomonitoring purposes in the long term. While Blood-Pb measurements are reflective of recent exposure, past exposures may also be represented in them, as a result of $\mathrm{Pb}$ mobilization from bone back into blood (Gulson et al. ${ }^{6}$ ). In those subjects lacking excessive exposure to $\mathrm{Pb}$, from 45 to $75 \%$ of the $\mathrm{Pb}$ in blood may have come from bone (Gulson et al.18, Smith et al.19). In exposed children, however, it has been reported that the Bone- $\mathrm{Pb}$ contribution to blood can be $90 \%$ or more (Gwiazda et al. 20 ). Thus, reductions in Blood- $\mathrm{Pb}$ levels after environmental $\mathrm{Pb}$ remediation may be buffered somewhat by contributions from endogenous lead sources (Lowry et al. ${ }^{21}$; Rust et al.14). Remediation efforts typically result in reductions of Blood-Pb levels in exposed children of no more than $30 \%$, when evaluated within several months after interven- tion (US EPA22). Roberts et al.23 reported that in children with Blood-Pb levels between 25-29 $\mu \mathrm{g} / \mathrm{dL}$ who not treated with chelation drugs, the time required for Blood- $\mathrm{Pb}$ to decline to $<10$ $\mu \mathrm{g} / \mathrm{dL}$ is about 2 years. Some workers have suggested that the efficacy of $\mathrm{Pb}$ hazard remediation efforts should be evaluated over extended periods, to allow adequate time for mobilization and depletion of accumulated skeletal $\mathrm{Pb}$ stores, and a reduction in the absolute contribution to blood lead levels from these stores (Gwiazda et al.20, Lowry et al.21). Thus, the mean of serial Blood-Pb levels should be a more accurate index of long-term $\mathrm{Pb}$ exposure.

Data collected as part of the US National Health and Examination Survey (NHANES) give the 95th percentile for blood $\mathrm{Pb}$ of 7.0 $\mu \mathrm{g} / \mathrm{dL}$ for children aged 1-5 years, and $5.20 \mu \mathrm{g} /$ $\mathrm{dL}$ for adults aged 20 years and older (CDC24). While current populations blood $\mathrm{Pb}$ levels in the US have dropped markedly compared to 30 years ago, new concerns have been raised regarding possible adverse health effects in children at Blood-Pb levels below $10 \mu \mathrm{g} / \mathrm{dL}$ : perhaps there is no safe threshold but, rather, a continuum of toxic effects (Canfield et al.25). In light of these concerns, the CDC Advisory Committee on Childhood Lead Poisoning Prevention formed a working group to review of the evidence for adverse health effects at Blood$\mathrm{Pb}$ levels $<10 \mu \mathrm{g} / \mathrm{dL}$ in children. Although this working group concluded that several studies in the literature had demonstrated a statistically significant association between Blood- $\mathrm{Pb}$ levels $<10 \mu \mathrm{g} / \mathrm{dL}$ as well as some adverse health effects in children, the effects were very small and could conceivably have been influenced by residual confounding factors. The working group's report called for further studies to examine the relationship between lower Blood- $\mathrm{Pb}$ levels and health outcomes, to provide a more complete understanding of this issue (CDC26).

Many studies have reported statistically significant associations between Blood-Pb levels and various health effect outcomes. Some, however, have been statistically weak, with the magnitude of the effect relatively small. According to $\mathrm{Hu}$ et al. ${ }^{27}$, such weaknesses of association may occur because Blood- $\mathrm{Pb}$ is not a sufficiently sensitive biomarker of exposure or dose at the target organ(s), or because the relationships involved are biologically irrelevant and are only found because of an uncontrolled confounding factor. Furthermore, in view of the kinetics of $\mathrm{Pb}$ distribution within the body 
(cycling between blood, bone, and soft tissues), differentiation of low-level chronic exposure from a short high-level exposure is not possible on the basis of a single Blood-Pb measurement ( $\mathrm{Hu}$ et al.27). Consequently, there is renewed interest in alternative biomarkers that may aid with better diagnosis of the extent of lead exposure. Such alternatives include $\mathrm{Pb}$ determinations in plasma/serum, saliva, bone, teeth, feces, and urine. However, none has gained convincing acceptance as an alternative to Blood-Pb. This is due in part to data based on erroneous or dubious analytical protocols that do not take into account the confounding variables.

\section{Plasma/serum lead}

Plasma- $\mathrm{Pb}$ likely represents a more relevant index of exposure to, distribution of, and health risks associated with $\mathrm{Pb}$ than does Blood-Pb. Indeed, from a physiological point of view, we can assume that the toxic effects of $\mathrm{Pb}$ are primarily associated with Plasma- $\mathrm{Pb}$, because this fraction is the most rapidly exchangeable one in the blood compartment. In recent years, increased attention is being paid to the monitoring of the concentration of $\mathrm{Pb}$ in plasma (or serum). However, research on associations between Plasma-Pb and toxicological outcomes is still quite rare, and a significant gap in knowledge remains.

Plasma/serum $\mathrm{Pb}$ levels in non-exposed and exposed individuals reported in older publications range widely from 0.02 to $14.5 \mu \mathrm{g} / \mathrm{L}$ (Versieck \& Cornelis ${ }^{28}$ ). This is probably due to the use of inappropriate collection methods, analytical instrumentation, and/or methods for $\mathrm{Pb}$ determination. The development and use of more sensitive analytical instrumentation, especially inductively coupled plasma mass spectrometry (ICP-MS), has resulted in determinations of $\mathrm{Pb}$ in plasma and serum specimens with much lower detection limits and with better accuracy. More recent data, also based on ICP-MS methods, have shown Plasma-Pb levels below $1.0 \mu \mathrm{g} / \mathrm{L}$ in non-exposed individuals (Schutz et al. ${ }^{29}$ ).

The use of advanced analytical techniques is not the only essential requirement to assure accurate and reliable Plasma-Pb data. Contamination of the specimen may occur at the preanalytical phase, i.e., during collection, manipulation or storage. Use of Class-100 biosafety cabinets and clean rooms for specimen preparation and analysis is mandatory. Moreover, all analytical reagents used must be of the highestpurity grade. These conditions are far more rigorous than are typically required for clinical Blood-Pb measurements as performed in a commercial laboratory. After the blood specimen has been collected, the serum/plasma separation must be performed as soon as possible, since there is high potential for $\mathrm{Pb}$ to move from the dominant Blood-Pb subcompartment repository, i.e., the erythrocytes, into the plasma via hemolysis, leading to erroneously high results for Plasma-Pb. Plasma hemolysis can be estimated by analyzing measurement of hemoglobin levels in the specimen, since these levels are likely to become abnormally elevated with hemolysis (Smith et al.30). Materials for specimen collection and storage, and the anticoagulant, must be of the highest quality, since these can be another source of $\mathrm{Pb}$ contamination.

Commercial evacuated blood tubes, prepared specifically for blood $\mathrm{Pb}$ measurements, are available with less than $5 \mu \mathrm{g} / \mathrm{L} \mathrm{Pb}$ (EsernioJenssen et al.31), but it is nevertheless desirable for the analyzing laboratory to characterize the background $\mathrm{Pb}$ contamination in each new lot of tubes, to ensure that reported concentrations are not compromised by contamination. The choice of anticoagulant is important, because EDTA, as a strong metal-chelating agent, may be difficult to obtain without some background contamination and/or may give misleadingly high Plasma- $\mathrm{Pb}$ results due to selective extraction of $\mathrm{Pb}$ bound to erythrocytes. The use of heparin has different associated problems because heparinized blood is more prone to form fibrin clots after several hours. These issues were evaluated by Smith et al. 32 in some detail; they compared commercial Vacutainer $^{\circledast}$ type tubes with ultracleaned collection tubes containing either EDTA or heparin. As there are no commercial blood collection tubes available that are certified for ultra-low $\mathrm{Pb}$ measurements, the analyzing laboratory should prepare pre-cleaned polyethylene tubes containing ultra low- $\mathrm{Pb}$ anticoagulants.

There are many reports of Plasma-Pb measurements where validation data are either weak or absent altogether. For example, some simply cite successful participation of the analyzing laboratory in quality assurance (QA) programs for whole blood $\mathrm{Pb}$ operated by the CDC and the College of American Pathologists (Hernandez-Avila et al.33), while others neglect 
to cite any kind of QA (Dombovari et al.34). Participation in QA schemes that are designed specifically for whole blood lead, while commendable, does not address the much more challenging analysis for Plasma-Pb. The problem is compounded by the lack of certified reference materials for either serum or plasma $\mathrm{Pb}$ (Cake et al.35). For these reasons, production of plasma or serum reference materials that have $\mathrm{Pb}$ concentrations certified close to current human values is urgently needed to support method validation.

\section{Saliva lead}

Saliva has been proposed as a diagnostic specimen for various purposes, as it is easily collected (Silbergeld ${ }^{36}$ ). However, in the absence of consistent and dependable saliva $\mathrm{Pb}$ measurements, it is not generally accepted as a reliable biomarker of $\mathrm{Pb}$ exposure. Saliva shows large variations in its ion content throughout the day, coupled with changes in salivary flow rates before, during, and after meals. Variations also arise depending on the manner in which saliva collection is stimulated (or not), and on the nutritional and hormonal status of the individual.

There are some data to suggest an association between $\mathrm{Pb}$ levels in saliva and those in either plasma or blood ( $\mathrm{Pan}^{37}$, Omokhodion \& Crockford ${ }^{38}$ ). Moreover, it has been argued that $\mathrm{Pb}$ in saliva is the direct excretion of the $\mathrm{Pb}$ fraction in diffusible plasma, i.e., the fraction not bound to proteins (Omokhodion \& Crockford ${ }^{38}$ ). Despite the associations reported in the literature, the older saliva $\mathrm{Pb}$ concentrations are quite high, and the values vary from study to study. On the other hand, recent data suggest much lower saliva $\mathrm{Pb}$ levels, in both exposed and unexposed subjects (Koh et al.39, Wilhelm et al.40). According to Wilhelm et al. $40, \mathrm{~Pb}$ content in the saliva of unexposed children is usually below $0.15 \mu \mathrm{g} / \mathrm{dL}$.

Uncontrolled variation in salivary flow rates, lack of standard or certified reference materials, and absence of reliable reference values for human populations are major factors that limit the utility of saliva $\mathrm{Pb}$ measurements. In addition, the very low levels of $\mathrm{Pb}$ present in saliva serve to limit the range of suitable analytical techniques thereby further diminishing the utility and reliability of this biomarker for prediction of $\mathrm{Pb}$ exposure.

\section{Hair lead}

Hair is a biological specimen that is easily and non-invasively collected, with minimal cost, and it is easily stored and transported to the laboratory for analysis. These attributes make hair an attractive biomonitoring substrate, at least superficially. Because lead is excreted in hair, many have suggested it for assessing $\mathrm{Pb}$ exposure, particularly in developing countries where specialized laboratory services may be unavailable and resources limited (Schumacher et al.41). However, there is an extensive debate ongoing about the limitations of hair as a biomarker of metal exposure generally. Here we limit the discussion to $\mathrm{Pb}$ exposure, although many of the issues for $\mathrm{Pb}$, such as pre-analytical concerns for contamination control, sampling and reference ranges, also apply to other metals.

The ability to distinguish between $\mathrm{Pb}$ that is endogenous, i.e., absorbed into the blood and incorporated into the hair matrix, and $\mathrm{Pb}$ that is exogenous, i.e., derived from external contamination, is a major problem. During the washing step, it is assumed that exogenous $\mathrm{Pb}$ is completely removed whereas endogenous $\mathrm{Pb}$ is not. However, no consensus exists about how removal of the former is best accomplished.

Some publications that describe the use of hair for assessing $\mathrm{Pb}$ exposure reference a hair washing method proposed by the International Atomic Energy Agency (IAEA) in 1978. The approach entailed washing of hair specimens with acetone/water/acetone (Ryabukin ${ }^{42}$ ). However, a recent study (Morton et al.43) has demonstrated that the IAEA method failed to remove exogenous $\mathrm{Pb}$ from hair.

Another issue is the significant variation in the $\mathrm{Pb}$ concentration profile among various subpopulations according to age, gender, haircolor, and smoking (Wolfsperger et al.44). Moreover, geographical, racial/ethnic, and ecological factors can also affect $\mathrm{Pb}$ distribution in hair within a given population. Thus, it is difficult to establish reference ranges, because confounding factors impose restrictions on the interpretation of individual results. No consensus exists on the length of the hair specimen to be collected, or the amount, or the position on scalp. Variations in $\mathrm{Pb}$ content between single hairs from the same individual can be as high as $\pm 100 \%$, particularly in the distal region (Renshaw et al.45).

Recently, the Agency for Toxic Substances and Disease Registry (ATSDR) established an 
expert advisory panel to review current knowledge on the use of hair analysis for trace metals in biomonitoring (ATSDR46). The general consensus was that many scientific issues need to be resolved before hair analysis can become a useful tool in understanding environmental exposures. Although hair analysis may be able to answer some specific questions about environmental exposure to a few substances, it often raises more questions than it answers. The scientific community currently does not know the range of $\mathrm{Pb}$ contamination levels typically found in human hair. Without reliable data, in the peer-reviewed literature, on baseline or background hair contamination levels in the general population, health agencies cannot determine whether results from a given site are unusually high or low, unless the data have been collected from comparison populations (ATSDR 46 ).

In addition to the pre-analytical issues and the absence of reliable reference ranges, the quality of analytical techniques used for determining $\mathrm{Pb}$, as well as other trace metals, in hair has been questioned. In a recent interlaboratory study of commercial laboratories that specifically market the test for trace metals in hair, interlaboratory agreement was judged very poor, with wide discrepancies observed for $\mathrm{Pb}$ as well as other elements (Seidel47). Other reports have also cautioned against the use of hair analysis for trace-metal assessment.

\section{Urinary and fecal lead}

The determination of lead in urine (Urine- $\mathrm{Pb}$ ) is considered to reflect $\mathrm{Pb}$ that has diffused from plasma and is excreted through the kidneys. Collection of urine for $\mathrm{Pb}$ measurements is non-invasive and is favored for long-term biomonitoring, especially for occupational exposures. However, a spot urine specimen is particularly unreliable, because it is subject to large biological variations that necessitate a creatinine excretion correction. Urine- $\mathrm{Pb}$ originates from plasma $\mathrm{Pb}$ that is filtered at the glomerular level; thus, according to some authors (Tsaih et al.48) urinary $\mathrm{Pb}$ levels that are adjusted for glomerular filtration rate may serve as a proxy for Plasma-Pb. Hirata et al. 49 found a better correlation between the concentration of Plasma-Pb and Urine- $\mathrm{Pb}$ than between $\mathrm{Blood}-\mathrm{Pb}$ and Urine- $\mathrm{Pb}$, for $\mathrm{Pb}$ workers with low levels of $\mathrm{Pb}$ exposure. Manton et al. ${ }^{7}$, using high-precision $\mathrm{Pb}$ isotope ratio measurements, found the concentration of Urine- $\mathrm{Pb}$ to be about $10 \%$ of that in whole blood; however, the correlations were not particularly robust. In contrast, correlations with isotopic ratios were excellent. According to Tsaih et al.48, cortical bone contributes a mean of $0.43 \mu \mathrm{g} \mathrm{Pb}$ per day excreted in urine, whereas trabecular bone contributes as much as $1.6 \mu \mathrm{g} \mathrm{Pb}$ per day. $\mathrm{Ca}-$ valleri et al. 50 observed different $\mathrm{Pb}$ kinetics between exposed and non-exposed subjects after the administration of $\mathrm{CaNa}_{2}$ EDTA. In unexposed subjects, Blood- $\mathrm{Pb}$ levels remained stable even after $5 \mathrm{~h}$ of $\mathrm{CaNa}_{2}$ EDTA administration. However, Plasma- $\mathrm{Pb}$ levels in the unexposed group decreased by as much as one-half, while Urine- $\mathrm{Pb}$ increased by a factor of 10 . In the $\mathrm{Pb}$-exposed group, the same amount of chelation therapy resulted in Plasma-Pb levels increasing by a factor of 2 while Blood- $\mathrm{Pb}$ levels decreased by a factor of 2, with a higher Urine- $\mathrm{Pb}$ excretion. Thus, it seems that in non-exposed subjects a major contribution for Urine- $\mathrm{Pb}$ is derived from the $\mathrm{Pb}$ fraction in soft tissues that is in equilibrium with that in plasma compartment. We could speculate that the larger the amount of erythrocyte-bound $\mathrm{Pb}$, the weaker the binding forces, and that a significant fraction of $\mathrm{Pb}$ is released from red blood cell membranes into plasma, and is then filtered by the kidney. Since the amount of $\mathrm{Pb}$ excreted is very high, the kidneys are unable to remove it rapidly from the blood stream; this may account for the temporal elevation of Plasma-Pb levels.

The availability of reliable urine quality control materials and reference materials certified for $\mathrm{Pb}$ content, and participation in external quality assessment schemes for urine $\mathrm{Pb}$, constitute important factors in assuring the accuracy of analytical results. However, the tendency for urate salts to precipitate out of urine during transit and storage can be a complicating factor in the analysis. Moreover, because only a few papers have examined associations between Urine- $\mathrm{Pb}$ and other biomarkers, the use of urinary $\mathrm{Pb}$ measurements is essentially limited to long-term occupational monitoring programs, monitoring patients during chelation-therapy and, until very recently, to clinical evaluation of potential candidates for chelation therapy.

Measurement of Fecal-Pb content over several days is one possible approach to estimating the overall magnitude of childhood $\mathrm{Pb}$ intake. According to Gwiazda et al. 20, Fecal Pb 
content should give an integrated measure of $\mathrm{Pb}$ exposure/intake from all sources, dietary and environmental, inside and outside the home (by isotopic composition). However, a limitation to the use Fecal- $\mathrm{Pb}$ is that the collection of complete fecal samples over multiple days may not be feasible. As stated by Gwiazda et al. 20 , Fecal-Pb reflects unabsorbed, ingested $\mathrm{Pb}$ plus $\mathrm{Pb}$ that is eliminated via endogenous fecal (biliary) routes; inter-individual variations in these physiologic processes may show up as variation that is wrongly attributable to environmental $\mathrm{Pb}$ exposure.

\section{Nail lead}

Like hair, nails possess many superficial advantages as a biomarker for $\mathrm{Pb}$ exposure, especially because specimen collection is non-invasive and simple, and because nail specimens are very stable after collection, not requiring special storage conditions. Nail- $\mathrm{Pb}$ is considered a reflection of long-term exposure, because this compartment remains isolated from other metabolic activities in the body (Takagi et al.51). Since toenails are less affected by exogenous environmental contamination than are fingernails, they have been preferred for $\mathrm{Pb}$ exposure studies. Toenails have a slower growth rate than fingernails (up to $50 \%$ slower, especially in winter) and thus may provide a longer integration of $\mathrm{Pb}$ exposure.

Lead concentration in nails depends on the subject's age (Nowak \& Chmielnicka ${ }^{52}$ ), but it seems do not depend on subject's gender (Rodushkin \& Axelsson ${ }^{53}$ ).

Gulson ${ }^{4}$ reported high variability in $\mathrm{Pb}$ levels measured in the same fingernails and toenails of various subjects, even after rigorous washing procedures; such lack of reproducibility suggests that nail specimens offer only limited scope in assessing exposure to $\mathrm{Pb}$.

\section{Bone lead}

Since bone accounts for more than $94 \%$ of the adult body burden of lead (70\% in children) (O'Flaherty10), many researchers accept that a cumulative measure of $\mathrm{Pb}$ dose may be the most important determinant of some forms of toxicity (cumulative measure means an exposure that is integrated over many years, rather than based on a single Blood-Pb measurement)
(Landrigan \& Todd55 1994; Hu et al.27). In support of this hypothesis, recent studies have shown that Bone- $\mathrm{Pb}$, but not Blood- $\mathrm{Pb}$, is significantly related to declines in hematocrit and hemoglobin among moderately $\mathrm{Pb}$-exposed construction workers, and to decreased birth weight among mothers and increased odds of clinically relevant hypertension ( $\mathrm{Hu}$ et al.56, Gonzalez-Cossio et al.57). According to $\mathrm{Hu}$ et al. 27 other adverse health outcomes that are likely to be better associated with Bone- $\mathrm{Pb}$ levels include impairment of cognitive performance and growth in children, and kidney failure, gout, elevated blood pressure, reproductive toxicity, and adverse cardiovascular events in adults.

As pointed by $\mathrm{Hu}$ et al. 27 two major paradigms relate to skeletal lead: Bone- $\mathrm{Pb}$ as an indicator of cumulative lead exposure (Bone- $\mathrm{Pb}$ as a repository), and Bone- $\mathrm{Pb}$ as a source of body burden that can mobilized into the circulation (Bone- $\mathrm{Pb}$ as a source). Hernandez-Avila et al. 33 reported a strong association between Bone-Pb levels and Serum-Pb levels of adults exposed to $\mathrm{Pb}$. That study indicated the potential role of the skeleton as an important source of endogenous labile $\mathrm{Pb}$ that may not be adequately discerned through measurement of Blood- $\mathrm{Pb}$ levels. The same authors argue that skeletal sources of $\mathrm{Pb}$ accumulated from past exposures should be considered, along with current sources, when exposure pathways are being evaluated. In an attempt to characterize the source of $\mathrm{Pb}$ exposure, Gulson et al.18 measured the $206 \mathrm{~Pb} / 204 \mathrm{~Pb}$ isotopic ratios in immigrant Australian subjects, Australian-born subjects and environmental samples. The immigrant population exhibited $\mathrm{Pb}$ isotopic ratios from 17.7 to 18.5 , distinct from the ratio in Australian-born subjects (approximately 17.0). This difference allowed a distinction to be drawn between current exposure, acquired from Australian sources, and older bone-stored $\mathrm{Pb}$ that was not acquired from Australian sources.

Differing bone types have differing Bone$\mathrm{Pb}$ mobilization characteristics. For example, the tibia principally consists of cortical bone, while the patella is largely trabecular bone. $\mathrm{Pb}$ in trabecular bone is more biologically active than is $\mathrm{Pb}$ in cortical bone, and trabecular bone has a shorter turnover time. The endogenous contribution of $\mathrm{Pb}$ from bone stores is an important health consideration. The O'Flaherty kinetic model can be used to indicate the quan- 
tity of $\mathrm{Pb}$ delivered from bone as a function of bone turnover and $\mathrm{Pb}$ exchange (O'Flaherty10). A recent revised version of this model (Fleming et al.58) suggests that a smeltery worker with a tibia $\mathrm{Pb}$ concentration of $100 \mu \mathrm{g} / \mathrm{g}$ can expect a continuous endogenous contribution to Blood-Pb of $16 \mu \mathrm{g} / \mathrm{dL}$. A pregnant woman with a tibia $\mathrm{Pb}$ concentration of $50 \mu \mathrm{g} / \mathrm{g}$ can end up with a contribution of $8-\mu \mathrm{g} / \mathrm{dL}$ Blood-Pb; this figure does not take into account the increased rate of bone turnover associated with pregnancy. Individuals who are not exposed to $\mathrm{Pb}$ in the workplace typically display tibia $\mathrm{Pb}$ levels up to about $20 \mu \mathrm{g} / \mathrm{g}$ (Roy et al.59).

Over the last decade, bone $\mathrm{Pb}$ measurements based on non-invasive in vivo X-ray fluorescence (XRF) methods have become increasingly accepted. The technique uses fluorescing photons to remove an inner-shell electron from a $\mathrm{Pb}$ atom, leaving it in an excited state. The result is emission of X-ray photons that are characteristic of $\mathrm{Pb}$. Measurements are performed by using one of four kinds of XRF: two involve fluorescence of the K-shell electrons of $\mathrm{Pb}$ (KXRF), and the other two involve fluorescence of the L-shell electrons (LXRF) (Todd et al.60). Several groups, mainly in North America have reported the development of in vivo measurement systems; the majority have adopted the KXRF approach based on excitation with a ${ }^{109} \mathrm{Cd}$ isotope and backscatter geometry, because of its advantages: it provides a robust measurement with a better detection limit and a lower effective (radiation) dose (as compared to LXRF) (Todd \& Chettle61). The radiation dose is not a limiting factor in using this technique with humans, as demonstrated by Todd \& Chettle61.

Calibration is usually performed with $\mathrm{Pb}$ doped plaster-of-Paris phantoms (Todd et al.60). Method accuracy has been evaluated through comparison of XRF data from cadaver specimens with ETAAS data (Todd et al.62). However, XRF sensitivity and precision for $\mathrm{Pb}$ still constitute an analytical challenge. In addition to sample-to-sample reproducibility, XRF can also display a certain amount of imprecision associated with each calculated bone lead value (Ambrose et al.63). This uncertainty, estimated using a goodness-of-fit statistic from the curve fitting of the background, ranged from 3 to 30 $\mu \mathrm{g} / \mathrm{g} \mathrm{Pb}$; clearly, this will represent a problem for measurements of low-level $\mathrm{Pb}$ (i.e., young children and non-exposed population). Another problem inherent to the XRF technique is photon scattering, due to overlying tissue or subject movement during the measurement period (Ambrose et al. 63). Normalization of the $\mathrm{Pb}$ signal to the $\mathrm{Ca}$ backscatter signal appears to solve this problem. Precision depends on the amount of tissue overlying the bone: the greater the thickness of tissue, the poorer the precision. Todd \& Chettle 61 comparing the Kshell with L-shell precisions with $3 \mathrm{~mm}$ and 6 $\mathrm{mm}$ of overlying soft tissue, reported that KXRF precision worsens by only $5 \%$, whereas LXRF precision worsens by $49 \%$ for greater thickness. The precision of the LXRF method is much more severely affected by the strong attenuation of the $\mathrm{Pb} \mathrm{L}$ X-rays.

Todd et al. 64 reported contiguous inhomogeneities in the distribution of $\mathrm{Pb}$ toward the proximal and distal ends of the tibia bones. They speculated that the region of lower $\mathrm{Pb}$ concentration has lower blood flow in the Haversian canals and, consequently, less $\mathrm{Pb}$ available for uptake into bone matrix during bone remodeling (Todd et al. 64). Trabecular bone has a larger surface area and a greater volume of blood delivered per unit time, compared to cortical bone. In addition, there are more active osteons per gram in trabecular bone to accomplish resorption and deposition. Hernandez-Avila et al. 33 reported that, in individuals with no history to occupational $\mathrm{Pb}$ exposure, Bone- $\mathrm{Pb}$ (in particular trabecular $\mathrm{Pb}$ ) exerts an additional independent influence on Plasma $\mathrm{Pb}$ after control for Blood-Pb.

Thus, an appropriate selection of the precise bone type to be analyzed for $\mathrm{Pb}$ content must be made before commencing. Moreover, further research on the relationship between various Bone- $\mathrm{Pb}$ sub-compartments and other $\mathrm{Pb}$ measures is warranted.

\section{Tooth lead}

Like bone, teeth accumulate $\mathrm{Pb}$ over the long term. However, there is some evidence that teeth are superior to bone as an indicator of cumulative $\mathrm{Pb}$ exposure, since the losses from teeth are much slower (Maneakrichten et al.65). Moreover, deciduous teeth are relatively easy to collect and analyze, since exfoliation generally occurs after the age of 6 years. Teeth are also very stable, for preservation purposes.

Chronic $\mathrm{Pb}$ exposure, from mouthing activity in early childhood, may be camouflaged by "dilution" effects during periods of rapid 
skeletal growth in young children and adolescents, and may not be detected by a single blood- $\mathrm{Pb}$ measurement. However, most of the published data based on Tooth- $\mathrm{Pb}$ have been based on whole tooth analysis, with no attempt to distinguish among tooth types (different teeth are formed at different ages), or to differentiate the $\mathrm{Pb}$ concentration in enamel from that in dentin (enamel contains much more $\mathrm{Pb}$, by mass, than does dentin). Also not considered has been the influence of age and/or gender (Brown et al.66). Furthermore, use of deciduous teeth is only possible for children over 6 years in age. Recently, Gomes et al.67 (2004) proposed a solution to the limitations mentioned above by using an in vivo enamel biopsy of children. In this approach, superficial minerals are leached from teeth and $\mathrm{Pb}$ determined by ETAAS. One important drawback to this approach is that, because an accumulation gradient for $\mathrm{Pb}$ has not yet been established for enamel, only biopsies of a given depth can be compared to one another. Another issue related to Tooth- $\mathrm{Pb}$ measurements is whether $\mathrm{Pb}$ that accumulates in the first few micrometers of the enamel surface was incorporated posteruptively, e.g., from the mouth, saliva, food, rather than during the period when the tooth was mineralized inside the bone.

An interesting, and potentially valuable aspect of Tooth- $\mathrm{Pb}$ measurements is their capacity to elucidate the history of $\mathrm{Pb}$ exposure. Teeth are composed of several distinct tissues formed over a period of several years, and different parts of the tooth can bind $\mathrm{Pb}$ at different stages of the individual's life. Therefore, a section of tooth can yield historical information on the individual's prior exposure to $\mathrm{Pb}$. For example, the enamel of all primary teeth, and parts of the enamel from some permanent teeth, are formed in utero and thus may provide information on pre-natal exposure to $\mathrm{Pb}$. This information could be valuable in improving our understanding of dose-effect relationships for embryonic anomalies, particularly neurotoxic dysfunction. The dentine of the primary teeth provides evidence of exposure during the early childhood years, when hand-tomouth activity is usually an important contributor to $\mathrm{Pb}$ body burden (Gulson 68 ). However, enamel $\mathrm{Pb}$ levels may be useful for indirectly estimating the $\mathrm{Pb}$ composition of the mother's bone (Gulson 68 ).

More recently, there has been some interest in using laser ablation - ICP-MS to examine $\mathrm{Pb}$ distribution in tooth profiles. This approach offers spatially resolved measurements of traceelement distribution that can be compared to a temporal axis via reference to the neonatal line, enabling researchers to use not only the $\mathrm{Pb}$ concentration of the entire tooth, but also the specific amount of $\mathrm{Pb}$ "stored" in each tooth layer, i.e., a time line of $\mathrm{Pb}$ exposure. Nevertheless, some serious challenges remain before this technique can be fully exploited (Uryu et al.69).

\section{Conclusions}

Thus far, an impressive body of data has been established based on the use of alternative biomarkers for monitoring exposure to $\mathrm{Pb}$. However, it is still unclear to what extent such data are superior to the information obtained from Blood-Pb measurements. Clearly, many of the limitations identified in the foregoing sections must be resolved, before alternative biomarkers can be accepted as superior indicators of $\mathrm{Pb}$ exposure. At this time, Blood- $\mathrm{Pb}$ measurements are still the most reliable indicator of recent lead exposure, although serial blood- $\mathrm{Pb}$ measurements may offer a better assessment of temporal fluctuations in $\mathrm{Pb}$ absorption. If reliable and reproducible Plasma- $\mathrm{Pb}$ measurements can be obtained, these may offer better correlation with toxic effects. However, we do not yet know what a single Plasma- $\mathrm{Pb}$ value means, in terms of health effects; in the absence of a normal reference range, the clinical utility for individual assessment is problematic. Further research on this issue is clearly needed, especially for children and adults with low to moderate $\mathrm{Pb}$ exposure. Further efforts are also warranted in the further development and continued use of well-established analytical protocols, as well as in the estimation of random and systematic errors. Efforts are needed to create regional reference ranges of non-exposed populations for each biomarker; to acquire data related to long-term and short-term exposures; and to evaluate the influence of nutritional status and ethnicity (genetic polymorphisms).

A critical question that might be asked, with respect to an individual's Bone- $\mathrm{Pb}$ measurement, is what does it mean in terms of health risk or, perhaps, clinical management? To answer this question, we may need to distinguish between Bone- $\mathrm{Pb}$ measurements in children and pregnant women, i.e., those with high 
bone turnover rate, compared to [non-pregnant] adults. In the former group, Bone- $\mathrm{Pb}$ may have little effect on Blood-Pb levels, but it may help us to estimate the extent to which Blood- $\mathrm{Pb}$ derives from endogenous sources, as well as its possible contribution to the labile Plasma-Pb pool.

\section{List of abbreviations}

\begin{tabular}{|c|c|c|c|}
\hline ALA-D & $\delta$-aminolevulinic acid dehydratase & KXRF & K-shell X-ray fluorescence \\
\hline ALA-U & Aminolevulinic acid in urine & LXRF & L-shell X-ray fluorescence \\
\hline ALA-B & Aminolevulinic acid in blood & $\mu \mathrm{g}$ & microgram \\
\hline ALA-P & Aminolevulinic acid in plasma & $\mu \mathrm{g} / \mathrm{L}$ & microgram per liter \\
\hline \multirow[t]{2}{*}{ ATSDR } & Agency for Toxic Substances and & $\mu \mathrm{g} / \mathrm{dL}$ & microgram per deciliter \\
\hline & Disease Registry & $\mu \mathrm{g} / \mathrm{g}$ & microgram per gram \\
\hline Blood-Pb & Lead levels in blood & $\mu \mathrm{g} / \mathrm{mL}$ & microgram per mililiter \\
\hline Bone-Pb & Lead levels in bone & $\mu \mathrm{g} / 24 \mathrm{~h}$ & microgram per day \\
\hline CaNa2EDTA & Edetate calcium disodium & $\mu \mathrm{mol} / \mathrm{L}$ & micromol per liter \\
\hline $\mathrm{Ca}$ & Calcium & NADS & Nicotinamide Adenine \\
\hline${ }^{109} \mathrm{Cd}$ & Cadmium isotope 109 & & Dinucleotide Synthase \\
\hline $\mathrm{CP}$ & Coproporphyrin & Nail-Pb & Lead levels in nail \\
\hline CDC & $\begin{array}{l}\text { Centers for Disease Control } \\
\text { and Prevention }\end{array}$ & NHANES & $\begin{array}{l}\text { National Health and Examination } \\
\text { Survey }\end{array}$ \\
\hline EDTA & Ethylenediamine Tetraacetic Acid & $\mathbf{P b}$ & Lead \\
\hline EP & Erythrocyte Protoporphyrin & $204 \mathrm{~Pb}$ & Lead isotope 204 \\
\hline \multirow[t]{2}{*}{ ETAAS } & Electrothermal Atomic & $206 \mathrm{~Pb}$ & Lead isotope 206 \\
\hline & Absorption Spectrometry & Plasma-Pb & Lead levels in plasma \\
\hline \multirow[t]{2}{*}{ ETV-ICP-MS } & Electrothermal Vaporization & P5’ N & Pyrimidine nucleotidase \\
\hline & Coupled to ICP-MS & QA & Quality Assurance \\
\hline $\mathrm{Fe}$ & Iron & Tooth-Pb & Lead levels in tooth \\
\hline Fecal-Pb & Lead levels in feces & Urine- $\mathrm{Pb}$ & Lead levels in urine \\
\hline Hair-Pb & Lead levels in hair & US EPA & United States Environmental \\
\hline $\mathrm{HCl}$ & Hydrocloric Acid & & Protection Agency \\
\hline \multirow[t]{2}{*}{ IAEA } & International Atomic Energy & XRF & X-ray fluorescence \\
\hline & Agency & WHO & World Health Organization \\
\hline \multirow[t]{2}{*}{ ICP-MS } & Inductively Coupled Plasma & $\mathrm{ZPP}$ & Zinc protoporphyrin \\
\hline & Mass Spectrometry & & \\
\hline
\end{tabular}




\section{Collaborators}

F. Barbosa Jr, JE Tanus-Santos, RF Gerlach and PJ Parsons have contributed equally during the manuscript preparation. Final version was set up by F Barbosa Jr and PJ Parsons.

\section{References}

1. Thomas VM, Socolow RH, Fanelli JJ, Spiro TG. 1999. Effects of reducing lead in gasoline: An analysis of the international experience. Environ Sci Techol 1999; 33:3942-48.

2. Wakefield J. The lead effect. Environ. Health Perspec 2002; 110:A574-A580.

3. National Research Council. Measuring lead exposure in infants children and other sensitive populations. Washington DC: National Academy Press; 1993.

4. Agency for Toxic Substances and Disease Registry (ATSDR). Toxicological profile for lead. US Department of Health and Human Services, Public Health Service; July 1999.

5. Rabinowitz MB, Wetherill GW, Kopple JD. Kinetic analysis of lead metabolism in healthy humans. J. Clin. Invest 1976; 58:260-70.

6. Gulson BL, Mizon KJ, Korsch MJ, Horwarth D, Phillips A, Hall J. Impact on blood lead in children and adults following relocation from their source of exposure and contribution of skeletal tissue to blood lead. Bull Environ Contam Toxicol 1996; 56:543-50.

7. Manton WI, Angle CR, Stanek KL, Reese YR, Kuehnemann TJ. Acquisition and retention of lead by young children. Environ Res 2000; 82:6-80.

8. Succop P, Bornschein R, Brown K, Tseng CY. 1998. An empirical comparison of lead exposure pathway models. Environ Health Perspect 1998; 106:1577-83.

9. Rabinowitz MB. Toxicokinetics of bone lead. Environ Health Perspect 1991; 91:33-7.

10. O'Flaherty EJ. Physiologically based models for bone-seeking elements. V. Lead absorption and disposition in childhood. Toxicol Appl Pharmacol 1995 131:297-308.

11. Brito JAA, McNeill FE, Webber CE, Wells S, Richard $\mathrm{N}$, Carvalho ML, Chettle DR. Evaluation of a nove structural model to describe the endogenous release of lead from bone. J Environ Monit 2002; 4:194-201.

12. Brito JAA, McNeill FE, Webber CE, Chettle DR. Grid search: an innovative method for the estimation of the rates of lead exchange between body compartments. J Environ Monit 2005; 7:241-47.

13. Barry PS. Concentrations of lead in the tissues of children. Br J Ind Med 1981; 38:61-71.

14. Rust SW, Kumar P, Burgoon DA, Niemuth NA, Schultz BD. Influence of bone-lead stores on the observed effective-ness of lead hazard intervention. Environ Res 1999; 81:175-84.

15. Popovic M, McNeill FE, Chettle DR, Webber CE, Lee $\mathrm{CV}$, Kaye WE. Impact of occupational exposure on lead levels in women. Environ Health Perspect 2005; 113:478-84.

16. Leung FY, Bradley C, Pellar TG. Reference intervals for blood lead and evaluation of zinc protoporphyrin as a screening-test for lead toxicity. Clin Biochem 1993; 26:491-96.

17. Sakai T. Biomarkers of lead exposure. Ind Health 2000; 38:127-42.

18. Gulson BL, Mahaffey KR, Mizon KJ, Korsch MJ, Cameron MA, Vimpani G. Contribution of tissue lead to blood lead in adult female subjects based on stable lead-isotope methods. J Lab Clin Med 1995; 125:703-12.

19. Smith DR, Osterloh JD, Flegal AR. Use of endogenous, stable lead isotopes to determine release of lead from the skeleton. Environ Health Perspect 1996; 104:60-6.

20. Gwiazda R, Campbell C, Smith D. A noninvasive isotopic approach to estimate the bone lead contribution to blood in children: Implication for assessing the efficacy of lead abatement. Environ Health Perspect 2005; 113:104-10.

21. Lowry LK, Cherry DC, Brady CFT, Huggins B, D'Sa AM, Levin JL. An unexplained case of elevated blood lead in a Hispanic child. Environ Health Perspect 2004; 112:222-5.

22. U.S Environmental Protection Agency. Review of Studies Addressing Lead Abatement Effectiveness. EPA 747-R-95-006. Washington, DC: U.S. EPA; 1995.

23. Roberts JR, Reigart JR, Ebeling M, Hulsey TC. Time required for blood lead levels to decline in nonchelated children. Clin Toxicol 2001; 39:153-60.

24. Centers for the Disease Control. Second National Report on Human Exposure to Environmental Chemicals, NCEH Pub. No. 02-0716. Atlanta, GA: CDC; 2003.

25. Canfield RL, Henderson CRJ, Cory-Slechta DA, Cox C, Jusko TA, Lanphear BP. Intellectual impairment in children with blood lead concentrations below $10 \mu \mathrm{g}$ per deciliter. N Engl J Med 2003; 348:1517-26.

26. Centers for the Disease Control. Work Group of the Advisory Committee on Childhood Lead Poisoning Prevention. A Review of The Evidence of health Effects of Blood Lead Levels $<10 \mu \mathrm{g} / \mathrm{dL}$ in Children. Centers for The Disease Control and Prevention [Accessed on February 2004]. CDC; 2004

27. $\mathrm{Hu} \mathrm{H}$, Rabinowitz M, Smith D. Bone lead as a biological marker in epidemiologic studies of chronic toxicity: Conceptual paradigms. Environ Health Perspect 1998; 106:1-8. 
28. Versieck J, Cornelis R. Trace elements in human plasma and serum. Florida: CRC Press, Boca Raton; 1988.

29. Schutz A, Bergdahl IA, Ekholm A, Skerfving S. Measurement by ICP-MS of lead in plasma and whole blood of lead workers and controls. Occup Environ Med 1996; 53:736-40.

30. Smith DR, Hernandez-Avila M, Tellez-Rojo MM, Mercado A, Hu $\mathrm{H}$. The relationship between lead in plasma and whole blood in women. Environ Health Perspect 2002; 110:263-68.

31. Esernio-Jenssen D, Bush V, Parsons PJ. Evaluation of vacutainer plus lo lead tubes for blood lead and erythrocyte protoporphyrin testing. Clin Chem 1999; 45:148-50.

32. Smith DR, Ilustre RP, Osterloh JD. Methodological considerations for the accurate determination of lead in human plasma and serum. Am J Ind Med 1998; 33:430-38.

33. Hernandez-Avila M, Smith D, Meneses F, Sanin LH, $\mathrm{Hu} \mathrm{H}$. The influence of bone and blood lead on plasma lead levels in environmental exposed adults. Environ Health Perspect 1998; 106:473-7.

34. Dombovari J, Varga Z, Becker JS, Matyus J, Kakuk G, Papp L. ICP-MS determination of trace elements in serum samples of healthy subjects using different sample preparation methods. Atom Spectrosc 2001; 22:331-5.

35. Cake KM, Bowins RJ, Vaillancourt C, Gordon CL, McNutt RH, Laporte R, Webber CE, Chettle DR. Partition of circulating lead between serum and red cells is different for internal and external sources of lead. Am J Ind Med 1996; 29:440-5.

36. Silbergeld EK. New approaches to monitoring environmental neurotoxins. Ann NY Acad Sci 1993; 694:62-71.

37. Pan AYS. Lead levels in saliva and in blood. J Toxicol Environ Health 1981; 7:273-80.

38. Omokhodion FO, Crockford GW. Lead in sweat and its relationship to salivary and urinary levels in normal healthy-subjects. Sci Total Environ 1991; 103:113-22.

39. Koh D, Ng V, Chua LH, Yang Y, Ong HY, Chia SE. Can salivary lead be used for biological monitoring of lead exposed individuals? Occup Environ Med 2003; 60:696-8.

40. Wilhelm M, Pesch A, Rostek U, Begerow J, Schmitz $\mathrm{N}$, Idel H, Ranft U. Concentrations of lead in blood, hair and saliva of German children living in three different areas of traffic density. Sci Total Environ 2002; 297:109-18.

41. Schuhmacher M, Domingo JL, Llobet JM, Corbella. Lead in children's hair, as related to exposure in Tarragona province, Spain. Sci Total Environ 1991; 104:167-73.

42. Ryabukin YS. Activation analysis of hair as an indicator of contamination of man by environmental trace element pollutants. IAEA Report IAEA/RL/50, Vienna, 1978.

43. Morton J, Carolan VA, Gardiner PHE. Removal of exogenously bound elements from human hair by various washing procedures and determination by inductively coupled plasma mass spectrometry. Anal Chim Acta 2002; 455:23-4.

44. Wolfsperger M, Hauser G, Gossler W, Schlagenhaufen, C. Heavy metals in human hair samples from Austria and Italy-Influence of sex and smoking-habits. Sci Total Environ 1994; 156:235-42.
45. Renshaw GD. Distribution of trace elements in human hair and its possible effect on reported elemental concentration levels. Med Sci Law 1976; 16:37-9.

46. Agency for Toxic Substances and Disease Registry (ATSDR). Hair Analysis Panel Discussion: Exploring the State of the Science. 2001. [Accessed on April 2005]. Available at www.atsdr.cdc.gov/HAC/hair_ analysis/.

47. Seidel S, Kreutzer R, Smith D, McNeel S, Gilliss D. Assessment of commercial laboratories performing hair mineral. JAMA 2001; 285:67-72.

48. Tsaih SW, Schwartz J, Lee MLT, Amarasiriwardena C, Aro A, Sparrow D, Hu H. The independent contribution of bone and erythrocyte lead to urinary lead among middle-aged and elderly men: The normative aging study. Environ Health Perspect 1999; 107:391-6.

49. Hirata M, Yoshida T, Miyajima K, Kosada H, Tabuchi T. Correlation between lead in plasma and other indicators of lead exposure among lead exposed workers. Int Arch Occup Environ Health 1995; 68:58-63.

50. Cavalleri A, Monoia C, Capodaglio E. Lead in plasma: Kinetics and biological effects. In: Facchett S, editor. Analytical Techniques for heavy metals in biological fluids. Amsterdam: Bsevier; 1981. p. 65-75.

51. Takagi, Y, Matsuda, S, Imai, S, Ohmori, Y, Vinson, JA, Mehra, MC et al. Survey of trace elements in human nails: an international comparison. Bull Environ Contam Toxicol 1988; 41:690-5.

52. Nowak B, Chmielnicka J. Relationship of lead and cadmium to essential elements in hair, teeth, and nails of environmentally exposed people. Ecotox Environ Safe 2000; 46:265-74.

53. Rodushkin I \& Axelsson MD. Application of double focusing sector field ICP-MS for multielemental characterization of human hair and nails. Part II. A study of the inhabitants of Northern Sweden. Sci Total Environ 2000; 262:21-36.

54. Gulson BL. Nails: Concern over their use in lead exposure assessment. Sci Total Environ 1996. 177:323-7.

55. Landrigan PJ, Todd AC. 1994. Direct measurement of lead in bone-A promising biomarker. JAMA 1994; 271:239-40.

56. Hu H, Aro A, Payton M, Korrick S, Sparrow D, Weiss ST, Rotnitzky A. The relationship of bone and blood lead to hypertension - The normative aging study. JAMA 1996; 275:1171-6.

57. Gonzalez-Cossio T, Peterson KE, Sanin LH, Fishbein E, Palazuelos E, Aro A, Hernandez-Avila M, Hu H. Decrease in birth weight in relation to maternal bone-lead burden. Pediatrics 1997; 100:856-62.

58. Fleming DEB, Chettle DR, Weber, CE, O'Flaherty EJ. The O'Flaherty model of lead kinetics: An evaluation using data from a lead smelter population. Toxicol Appl Pharmacol 1999; 161:100-9.

59. Roy MM, Gordon CL, Beaumont LF, Chettle DR, Weber CE. Further experience with bone lead content measurements in residents of Southern Ontario. Appl Radiat Isot 1997; 48:391-6.

60. Todd AC, Carroll S, Geraghty C, Khan FA, Moshier EL, Tang S, Parsons PJ. L-shell X-ray fluorescence measurements of lead in bone: accuracy and precision. Phys Med Biol 2002; 47:1399-419.

61. Todd AC, Chettle DR. In vivo X-ray fluorescence of lead in bone: review and current issues. Environ Health Perspect 1994; 102:172-7.

62. Todd AC, Parsons PJ, Carroll S, Geraghty C, Khan 
FA, Tang S, Moshier EL Measurements of lead in human tibiae. A comparison between K-shell x-ray fluorescence and electrothermal atomic absorption spectrometry. Phys Med Biol 2002; 47:673-87.

63. Ambrose TM, Al-Lozi M, Scott MG. Bone lead concentrations assessed by in vivo $\mathrm{X}$-ray fluorescence. Clin Chem 2000; 46:1171-8.

64. Todd AC, Parsons PJ, Tang SD, Moshier EL. Individual variability in human tibia lead concentration. Environ Health Perspect 2001; 109:1139-43.

65. Maneakrichten M, Patterson C, Miller G, Settle D, Erel Y. Comparative increases of lead and barium with age in human tooth enamel, rib and ulna. $S c i$ Total Environ 1991; 107:179-203.

66. Brown CJ, Chenery SRN, Smith B, Tomkins A, Roberts GJ, Serunjogi L, Thompson M A. Sampling and analytical methodology for dental trace element analysis. Analyst 2002; 127:319-23.
67. Gomes VE, de Sousa MDLR, Barbosa F, Krug FJ, Saraiva MDCP, Cury JA, Gerlach RF. In vivo studies on lead content of deciduous teeth superficial enamel of preschool children. Sci Total Environ 2004; 320:25-35.

68. Gulson BL.Tooth analyses of sources and intensity of lead exposure in children. Environ Health Perspect 1996; 104:306-12.

69. Uryu T, Yoshinaga J, Yanagisawa Y, Endo M, Takahashi J. Analysis of lead in tooth enamel by laser ablation-inductively coupled plasma-mass spectrometry. Anal Sci 2003; 19:1413-16.

Artigo apresentado em 11/01/2005

Aprovado em 10/08/2005

Versão final apresentada em 10/08/2005 